\title{
Fragile democracies and constitutional crises: a laboratory for studying the role of constitutional constraints
}

\section{Introductory essay for special issue of CPE, introduction essay by Monika Nalepa (The University of Chicago) and Emilia Justyna Powell (University of Notre Dame)}

\section{Monika Nalepa ${ }^{1} \cdot$ Emilia Justyna Powell ${ }^{2}$}

Accepted: 19 July 2021 / Published online: 26 July 2021

(c) The Author(s), under exclusive licence to Springer Science+Business Media, LLC, part of Springer Nature 2021

In the late nineties, Barry Weingast argued that constitutional enforcement requires coordinated social responses to transgressions (Weingast, 1997). Courts step in when it is unclear if a transgression occurred. The constitutional courts provide focal points for how to interpret the constitution (Vanberg, 2020). In many instances, there is no doubt about the constitutionality of legislation. Consider, as an example Donald Trump's so-called "Muslim ban" which he had to walk back merely a few days later.

In countries with a long-established tradition of judiciary independence, constitutional courts do not need to intervene all that frequently to exert their power. The sheer anticipation of their intervention is typically enough to prevent the executive from going down the path of unconstitutional legislation. In young democracies, where the rule of law tradition is still in its infancy and there are considerably more issues that call for clarification from Constitutional Courts; the anticipation of having key pieces of legislation struck down serves as a temptation for ruling governments to weaken the authority of constitutional courts.

In part because the constitutions themselves are younger, but also, in part, because their societies are not yet well socialized to the ideas of rule of law, when constitutional crisis strikes a young democracy, the stakes are high. human rights, such as rights of religious and ethnic minorities, are endangered. The dilemma of how to guarantee individual rights at times of constitutional jeopardy is a pressing

Monika Nalepa

mnalepa@uchicago.edu

Emilia Justyna Powell

epowell4@nd.edu

1 The University of Chicago, Pick Hall 324A, 5838 S University Ave, Chicago, IL 60615, USA

2 Department of Political Science, University of Notre Dame, Notre Dame, USA 
one and young democracies being more sensitive to such crises, offer a laboratory for designing and studying such responses in more mature democracies.

The articles collected in this issue come from a conference organized on the topic of constitutional crises and human rights at the University of Chicago in May of 2017 with the help of the Center for East European and Russian/Eurasian Studies and the Pozen Family Center for Human Rights.

The importance of Constitutional Court intervention became apparent in Hungary, in 2013, when Viktor Orban began passing constitutional amendments disregarding a 20-year history of verdicts from constitutional courts banning such maneuvers. Eventually, Orban took down the court itself.

Shortly later, Poland's Law and Justice (PiS) party started introducing similar legislation leading to the weakening of the judicial branch.

Ironically, merely five years earlier, both Hungary and Poland were held up as exemplars of a successful transition to democracy with strong adherence to rule of law.

The opening article of this volume, "Transitional Justice and authoritarian backsliding" by Monika Nalepa (2021) builds on existing theories of democratic backsliding and uses survey data collected in Poland to explore how countries so attached to democratic values could start reelecting into office aspiring autocrats. Paradoxically, she finds that an unfinished transitional justice project gave Law and Justice party (PiS) the excuse and pretext to start packing the courts.

Nalepa's paper is an analysis of the constitutional crisis unfolding in Poland after 2015. PiS almost immediately upon coming to power began implementing a far-reaching program of judicial reform starting with a reshuffle and reorganization of the Constitutional Tribunal (which is what the constitutional court in Poland is called). These reforms came at a time when critical PiS-sponsored legislation was awaiting constitutional courts decisions. Among the bills awaiting constitutional review were bills concerning national security, allowing the secret service to wiretap and access phone records and electronic data even to preempt criminal activity. Other bills awaiting decisions included legislation regulating the right to assembly, educational reform, and-down the line-reproductive rights.

Aside from reshuffling the Constitutional Tribunal, the PiS government proposed judicial reforms aimed at "flattening" the structure of the judiciary and accelerating disciplinary action towards justices. In the Supreme Court, any judge over 65 was forced into retirement, unless he or she secured special "exemption" from the Minister of Justice. Aside from increasing efficiency, the judicial reform was part of the ruling party's delivery on the promise to "complete the de-communization" of Poland or its "de-ubekization" (UB was the acronym of the communist secret police). This is the main thesis of Nalepa's article: that PiS used the leniency of transitional policies in regard to the judicial branch as an opening to carry out farreaching reforms.

Turkey, another country discussed in this volume was on the verge of consideration for joining the EU and was used repeatedly as an example of a successful secular democracy with a Muslim majority. Today it is probably the most frequently cited backsliding country next to Poland and Hungary. In her article, "Riding the Democracy Train: Incumbent-led Paths to Democracy" Ipek Cinar (2021) uncovers 
why of all instruments to strengthen their grip on power, aspiring autocrats choose the constitutional route. Following an unsuccessful coup d'état Erdogan could have chosen the path so frequently followed in Turkey before: that of a violent crackdown. Yet instead, he proposed a change to the constitution effectively switching the country from a parliamentary to a presidential regime and subjected the change to a popular referendum. The puzzling desire to masquerade an authoritarian power-grab in the draping of a constitutional democracy is explained by Cinar with a formal model that accounts for the informal authority the incumbent enjoys with the electorate as well as the constitutional gains of the incumbent if his presidential plan goes through.

Presidential regimes are only more convenient for would-be autocrats if they can stay in power forever (Przeworski, 2018). In Latin America, this means lifting term limits for presidential office and is the topic of Zachary Elkins's (2021) article entitled "Term-limit evasions and the non-compliance Cycle: a militant approach." Elkins focuses on several aspects of state governance associated with term limits and discusses a socio-economic and political culture that seems to provide fertile environment for executive encroachment. Elkins shows that despite the fact that nearly every Latin American country has imposed some kind of term limit on Presidents, many have successfully managed to avoid these limits. These deeply troublesome patterns suggest the appearance of deeply-seated-and perhaps even widely accepted-culture that accommodates executive evasion of term limits. Although some of these overstays are extra-constitutional — thus are not in any way sanctioned by written higher law-quite a few are assisted by the constitution or associated with an inauguration of a new constitution. Elkins refers to the later type as "reset overstays." Elkins theorizes a noncompliance cycle that has emerged in Latin America and normalizes the term-limit evasion and in turn promotes noncompliance across other areas of law ("other limits are just as discretionary, albeit with the right justification and legal adjustment").

While Elkins' analysis focuses on elites, Milena Ang and Yuna Blajer de la Garza (2021) in "Vulnerability, due process, and reform in modern Mexico" focus on those who the courts are supposed to serve in the context of contemporary Mexico, and in particular the country's 2008 penal reform.

In their article, they study the intricate relationship between socioeconomic vulnerabilities and violations of due process in modern time Mexico. The authors ask a crucial question, "Do institutional reforms-such as the provision of public defenders-help the most vulnerable groups in the population?" Ang and Blajer de la Garza show that in modern Mexico's institutional reforms of the legal system has done more that "merely pay lip service to the discourse of equal treatment and the rule of law." Using a rich survey of the imprisoned population in Mexico, the authors demonstrate that allocation of public defenders to those in need, overall helps reduce violations of due process for all groups. This finding is particularly important because due process abuses-fabrication of evidence, torture, unjust incarceration, and so on- are more prevalent among individuals who are already vulnerable, such as people with little schooling, indigenous populations, and women. Such reality affects considerable part of Mexico's population placing these people in a recurring cycle of victimization while interacting with the state. Though not counterintuitive, 
this finding has not been previously documented through quantitative analysis in Mexico's context. In more than one way, Ang and Blajer de la Garza's study constitutes the first in-depth empirical assessment of the lingering problem.

Yet, at the same time, the authors document that this improvement mostly benefited those who were less at risk of suffering due process violations in the first place: individuals with more years of formal education, men, and non-indigenous people. People with fewer years of schooling, women, and members of indigenous populations benefitted as well, but not as much as others. Thus, the reform's arguable objective-to address widespread violations in due process, and their effects especially among vulnerable populations - seems to have fallen short. It is the reform's overall success that obscures these fissures and heterogeneities.

The final article in this volume also explores the effect of formal constitutional language on aspects of democracy that pertain to regular citizens. The paper of Emilia Justyna Powell, Steven Christian McDowell, Robert O'Brien and Julia Oksasoglu (2021), "Islam-based legal language and state governance: democracy, strength of the judiciary and human rights" explores the intricate link between levels of electoral democracy, protections for private liberties, women's rights on the one hand and Islam-based legal language on the other. The authors set to decipher whether-and if so, how - the presence of Islam-based legal language in domestic legal systems is associated with lower levels of these select features of democracy. The central claim of the Powell et al. contribution is that Islamic Law States (ILS) do not constitute a monolithic category (Powell 2015, 2020). Instead, ILS' domestic legal systems vary along an important dimension: the balance of Islamic law and secular law, which is meaningfully reflected in these states' constitutional and subconstitutional legal systems. While some ILS including Iran or Saudi Arabia include references to Islam throughout their legal system, others, such as Morocco or Tunisia, limit the compulsory implementation of Islamic law to a fraction of their legal system, such as family law.

Focus on this diversity of legal arrangements in ILS allows the authors to challenge some of the wisdom regarding Islam's place and role in state governance. Going beyond the existing measures of "Islamicity," the Powell et al. paper uses factor analysis to measure the presence of Islam-based legal language in ILS' legal systems. The empirical analyses demonstrate that the presence of Islam-based legal language at different levels of a domestic legal system-constitutional and subconstitutional-is associated with diverse aspects of governance. For instance, the strength of the domestic judiciary, political liberties, and freedom from physical violence are not threatened by the mere existence of Islam-based legal language. Indeed, many positive rights embraced by state governance in a free society are simultaneously incorporated in the creeds of Islamic legal tradition.

In contrast, ILS legal systems permeated with Islam-based legal language are lacking in protections for private liberties and the rights of women. Importantly, the paper shows that it is the legal system as a whole-not merely constitutions-that impacts daily lives of citizens in Islamic law states. Importantly, though constitutions shape and constrain ordinary legislation and codes, in the context of many aspects of state governance, it is the subconstitutional legal system that has the capacity to restrain or further enable constitutional aspirations. As such, constitutional drafters, 
and more generally policymakers, should grant much attention to the design and functioning of institutions meant to carry out goals enshrined in a constitution. Indeed, the ordinary legislation in conjunction with institutions orchestrate the dayto-day functioning of the constitution.

\section{References}

Ang, M. and Y. Blajer de la Garza (2021). Vulnerability, due process, and reform in modern Mexico. Constitutional Political Economy. https://doi.org/10.1007/s10602-020-09305-7

Cinar, I. (2021). Riding the Democracy Train: Incumbent-led Paths to Democracy. Constitutional Political Economy. https://doi.org/10.1007/s10602-021-09340-y

Elkins, Z. (2021). Term-limit evasions and the non-compliance cycle. Constitutional Political Economy. https://doi.org/10.1007/s10602-021-09332-y

Nalepa, M. (2021). Transitional justice and authoritarian backsliding. Constitutional Political Economy. https://doi.org/10.1007/s10602-020-09315-5

Powell, E. J. (2015). Islamic law states and peaceful resolution of territorial disputes. International Organization, 69(4), 777-807.

Powell, E.J. (2020). Islamic law and international law: Peaceful resolution of disputes. New York: Oxford University Press.

Powel, E.J., S.C. McDowell, R. O'Brien and J.Oksasoglu (2021). Islam-based legal language and state governance: democracy, strength of the judiciary and human rights. Constitutional Political Economy. https://doi.org/10.1007/s10602-019-09298-y

Przeworski, A. (2018). Why Bother with Elections?. Polity Press.

Vanberg, G. (2020). Establishing judicial independence in West Germany: The impact of opinion leadership and the separation of powers. Comparative Politics, 32(3), 333-353.

Weingast, B. R. (1997). The Political foundations of democracy and the rule of law. American Political Science Review, 91(2), 245-263.

Publisher's Note Springer Nature remains neutral with regard to jurisdictional claims in published maps and institutional affiliations. 